\title{
Comparative Study on UV-AOPs for Efficient Continuous Flow Removal of 4-tert-Butylphenol
}

\author{
Saule Mergenbayeva (i) and Stavros G. Poulopoulos * $*$ (1) \\ Department of Chemical and Materials Engineering, School of Engineering and Digital Sciences, \\ Nazarbayev University, 53 Kabanbay Batyr Ave., Nur-Sultan 010000, Kazakhstan; \\ saule.mergenbayeva@nu.edu.kz \\ * Correspondence: stavros.poulopoulos@nu.edu.kz; Tel.: +7-7172-694-608
}

Citation: Mergenbayeva, S.;

Poulopoulos, S.G. Comparative Study on UV-AOPs for Efficient Continuous Flow Removal of 4-tert-Butylphenol. Processes 2022, 10, 8. https://doi.org/ $10.3390 /$ pr10010008

Academic Editor: Dimitris Zagklis

Received: 6 December 2021

Accepted: 14 December 2021

Published: 22 December 2021

Publisher's Note: MDPI stays neutral with regard to jurisdictional claims in published maps and institutional affiliations.

Copyright: (c) 2021 by the authors. Licensee MDPI, Basel, Switzerland. This article is an open access article distributed under the terms and conditions of the Creative Commons Attribution (CC BY) license (https:// creativecommons.org/licenses/by/ $4.0 /)$.

\begin{abstract}
In the present study, UV-light-driven advanced oxidation processes (AOPs) have been employed for the degradation of 4-tert-Butylphenol (4-t-BP) in water under continuous flow conditions. The effects of varying space time $(10,20,40,60$ and $120 \mathrm{~min})$ and oxidant dosage $(88.3 \mathrm{mg} / \mathrm{L}$, $176.6 \mathrm{mg} / \mathrm{L}$ and $264 \mathrm{mg} / \mathrm{L}$ ) were examined. 4-t-BP degradation efficiency in the UV-induced AOPs followed the order of $\mathrm{UV} / \mathrm{H}_{2} \mathrm{O}_{2}(264.9 \mathrm{mg} / \mathrm{L}) \approx \mathrm{UV} / \mathrm{Fe}^{2+} / \mathrm{H}_{2} \mathrm{O}_{2}>\mathrm{UV} / \mathrm{Fe}^{3+} / \mathrm{H}_{2} \mathrm{O}_{2}>\mathrm{UV} / \mathrm{H}_{2} \mathrm{O}_{2}$ $(176.6 \mathrm{mg} / \mathrm{L})>\mathrm{UV} / \mathrm{H}_{2} \mathrm{O}_{2}(88.3 \mathrm{mg} / \mathrm{L})>\mathrm{UV} / \mathrm{Fe}-\mathrm{TiO}_{2}>\mathrm{UV} / \mathrm{TiO}_{2}>\mathrm{UV}$, while $\mathrm{UV} / \mathrm{Fe}^{3+} / \mathrm{H}_{2} \mathrm{O}_{2}$ was the most efficient process in terms of Total Organic Carbon (TOC) removal (at the space time of $60 \mathrm{~min}$ ) among those tested. The combination of UV with $88.3 \mathrm{mg} / \mathrm{L} \mathrm{H}_{2} \mathrm{O}_{2}$ enhanced pollutant removal from $51.29 \%$ to $93.34 \%$ after 10 min of irradiation. The presence of $\mathrm{H}_{2} \mathrm{O}_{2}$ contributed to the highest 4-t-BP and TOC removal values. Interestingly, the increase in space time from 20 to $60 \mathrm{~min}$ resulted in surpassing of the activity of the $\mathrm{Fe}-\mathrm{TiO}_{2}$ over commercial $\mathrm{TiO}_{2}$, although it had an almost negligible positive impact on the performance of the $\mathrm{UV} / \mathrm{H}_{2} \mathrm{O}_{2}$ system as well as $\mathrm{H}_{2} \mathrm{O}_{2}$ concentration. The results obtained showed that more than $80 \%$ of 4 -t-BP could be successfully degraded by both heterogeneous and homogeneous AOPs after $60 \mathrm{~min}$.
\end{abstract}

Keywords: UV-based advanced oxidation processes; continuous flow; 4-tert-Butylphenol; degradation

\section{Introduction}

The contamination of water with various chemical compounds found in various types of water bodies [1-3] at low concentrations [4] has attracted increasing attention. These compounds have been termed as emerging pollutants (EPs) and include persistent organic compounds such as pharmaceuticals, personal care products (PCPs), and endocrine disruptive compounds (EDCs) with a high potential of bioaccumulation [5].

Among these pollutants, EDCs constitute a family of organic compounds that affect natural hormones [6]. Their widespread use has led to their release and accumulation in the aquatic environment [7,8]. For example, 4-tert-Butylphenol (4-t-BP), a representative of EDCs [9-12], has been detected in wastewater effluents and surface waters [6,13]. 4-t-BP is an alkylphenol used for the production of phenolic, polycarbonate, and epoxy resins [6]. Though detected at low concentrations in the environment, its ability to bind to the estrogen receptor [14] could result in serious damages for aquatic ecosystems and living organisms [15,16]. Due to its estrogenic activity [10], 4-t-BP has been included by the European Commission in the list of chemicals of very high concern since 2019 [17]. Thus, its toxicity $[18,19]$ and persistence $[20,21]$ impose the elimination of 4-t-BP in water.

Relatively few studies have been conducted to remove 4-t-BP from the aqueous environment; biodegradation and photochemical treatments have been applied mostly. However, biodegradation is not effective since long treatment times are necessary for the complete decomposition of 4-t-BP [22-24]. For instance, the presence of Spirodela polyrrhiza duckweed in environmental water samples led to 4 -t-BP removals up to $56 \%$ in a 3-day cycle at $28^{\circ} \mathrm{C}$ [25]. 
AOPs are attractive alternatives due to their low cost and environmentally friendly nature. The oxidation efficiency of these processes relies on the generation of highly reactive species such as hydroxyl radicals that have the capacity to degrade and mineralize recalcitrant organic pollutants [26-28]. Among them, $\mathrm{UV} / \mathrm{H}_{2} \mathrm{O}_{2}$, photo-Fenton, photo-Fenton-like, and heterogeneous photocatalytic processes are gaining increasing popularity $[12,13,29,30]$. For instance, 4-t-BP at the concentration of $0.1 \mathrm{mM}$ in water was almost completely removed within $50 \mathrm{~min}$ by $\mathrm{UV} / \mathrm{H}_{2} \mathrm{O}_{2}$ [12]. Xiao et al. [31] studied the treatment of 4-t-BP under visible light heterogeneous photocatalysis, and achieved a $95 \%$ TOC reduction after $120 \mathrm{~min}$.

Although a substantial amount of research has demonstrated the effectiveness of UVinduced AOPs in the removal of traditional hazardous compounds and many of emerging concern in water, most studies have been conducted in batch systems. The experimental comparison of low power $280 \mathrm{~nm} \mathrm{UV}$-photolysis, $\mathrm{UV} / \mathrm{H}_{2} \mathrm{O}_{2}$ and $\mathrm{UV} / \mathrm{TiO}_{2}$ towards the degradation of $1 \mathrm{H}$-benzotriazole demonstrated the superior performance of the $\mathrm{UV} / \mathrm{TiO}_{2}$ system in terms of degradation and mineralization [32]. Peternel et al. [33] reported about 2.5 higher mineralization efficiency for the photo-Fenton process compared with the $\mathrm{UV} / \mathrm{TiO}_{2}$ system for the organic reactive dye degradation in aqueous solution under $254 \mathrm{~nm}$ irradiation. Similarly, Martinez-Costa et al. [34] compared the performance of photo-Fenton processes and $\mathrm{UV} / \mathrm{H}_{2} \mathrm{O}_{2}$ for the removal of the antibiotics sulfamethoxazole (SMX) and trimethoprim (TMP) in aqueous solution. It was found that $\mathrm{UV} / \mathrm{H}_{2} \mathrm{O}_{2}$ was beneficial towards the mineralization of organic pollutant than photo-Fenton processes. Despite their promising results, lab scale batch experiments have the disadvantage of low efficiency for treating high volumes of polluted water [35]. In contrast, continuous flow systems appear to overcome such obstacles [36,37]. Silva et al. [38] studied photocatalytic degradation of SMX under simulated solar light in ultrapure water and environmental water matrices (fresh, estuarine and STP effluent). The results showed a sharp decrease in the irradiation time required for the removal of SMX under continuous flow conditions as compared with batch. Shojaeimehr et al. [39] assessed the photocatalytic degradation of diclofenac using porous carbon nitride $(\mathrm{mp}-\mathrm{CN})$ immobilized onto stainless steel (SS) plates and determined the optimum operating conditions, including catalyst loading, irradiation source and initial pollutant concentration. They concluded that the combination of continuous flow mode with the immobilized photocatalyst particles could be a promising alternative for treating contaminated water. Senthilnathan and Philip and Vishnuganth et al. [40] have also reported the effective light-driven pesticide removal using heterogeneous catalysts, $\mathrm{N}$-doped $\mathrm{TiO}_{2}$ and granular activated carbon-supported titanium dioxide $\left(\mathrm{GAC}-\mathrm{TiO}_{2}\right)$, respectively.

In the present study, the efficiency of UV-light-driven AOPs $\left(\mathrm{UV} / \mathrm{H}_{2} \mathrm{O}_{2}, \mathrm{UV} / \mathrm{Fe}^{2+} / \mathrm{H}_{2} \mathrm{O}_{2}\right.$ and $\mathrm{UV} / \mathrm{Fe}^{3+} / \mathrm{H}_{2} \mathrm{O}_{2}, \mathrm{UV} / \mathrm{TiO}_{2}$ and $\mathrm{UV} / \mathrm{Fe}-\mathrm{TiO}_{2}$ ) in terms of 4-t-BP degradation and total organic carbon removal was comparatively investigated under continuous flow conditions. To the best of our knowledge, this is the first study concerning the use of light-driven AOPs in continuous flow for the treatment of 4-t-BP in water by means of homogeneous and heterogeneous processes.

\section{Materials and Methods}

\subsection{Chemicals and Materials}

4-t-BP (99\%), $\mathrm{TiO}_{2}-\mathrm{P} 25$ (21 nm particle size, $\geq 99.5 \%$ ), $\mathrm{FeCl}_{2}(98 \%), \mathrm{FeSO}_{4} \cdot 7 \mathrm{H}_{2} \mathrm{O}$ $(\geq 99.0 \%), \mathrm{Fe}\left(\mathrm{NO}_{3}\right)_{3} \cdot 9 \mathrm{H}_{2} \mathrm{O}(\geq 98.0 \%)$ and methanol $(\mathrm{MeOH})$ of HPLC grade were obtained from Sigma Aldrich. $\mathrm{H}_{2} \mathrm{O}_{2}(37.6 \% w / w)$ was obtained from Skat-Reactiv Company (Almaty, Kazakhstan). Fe-doped $\mathrm{TiO}_{2}$ powders $\left(\mathrm{Fe}-\mathrm{TiO}_{2}\right)$ were synthesized by the wet impregnation

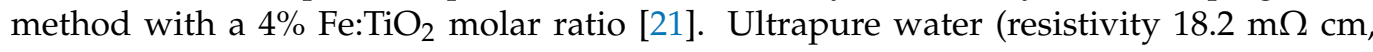
Millipore) was used to prepare all solutions. 


\subsection{Experimental Procedures}

A $1000 \mathrm{~mL}$ stock solution was prepared by dissolving $30 \mathrm{mg}$ of 4-t-BP in ultrapure water. Depending on the system, $\mathrm{H}_{2} \mathrm{O}_{2}$, iron, $\mathrm{TiO}_{2}$ or $\mathrm{Fe}-\mathrm{TiO}_{2}$ were added directly to the 4-t-BP solution before being exposed to UV light. The solution was kept under constant stirring using a digital ceramic top hotplate stirrer (Mettler Toledo). In $\mathrm{UV} / \mathrm{H}_{2} \mathrm{O}_{2}$ processes, three different concentrations of $\mathrm{H}_{2} \mathrm{O}_{2}(88.3 \mathrm{mg} / \mathrm{L}, 176.6 \mathrm{mg} / \mathrm{L}$ and $264.9 \mathrm{mg} / \mathrm{L})$ were used, while $5 \mathrm{mg} / \mathrm{L}$ of iron $\left(\mathrm{Fe}^{2+}\right.$ or $\left.\mathrm{Fe}^{3+}\right)$ was added in photo-Fenton and photo-Fenton-like processes. In $\mathrm{UV} / \mathrm{TiO}_{2}$ and $\mathrm{UV} / \mathrm{Fe}-\mathrm{TiO}_{2}$ processes, $200 \mathrm{mg} / \mathrm{L}$ of catalyst was tested.

The experiments on the degradation of 4-t-BP were carried out in a $300 \mathrm{~mL}$ photoreactor equipped with a 10W UV lamp (Figure 1). The reactor was cylindrical with an external diameter of $50.8 \mathrm{~mm}$ and a length of $90 \mathrm{~mm}$. Inlet flow rates ranged from 2.5 to $30 \mathrm{~mL} / \mathrm{min}$ with the help of a peristaltic pump (Ismatec REGLO pump; IDEX Corporation, Lake Forrest, IL, USA). Ambient conditions of temperature and pressure were used, and approximately neutral $\mathrm{pH}$ conditions $(6.7-7.1)$. Then, $15 \mathrm{~mL}$ aliquots of the treated solution were taken at different space times (10; 20; 40; 60 and $120 \mathrm{~min}$ ) and filtered by means of $0.22 \mu \mathrm{m}$ nylon filters. Each experiment was carried out in duplicates.

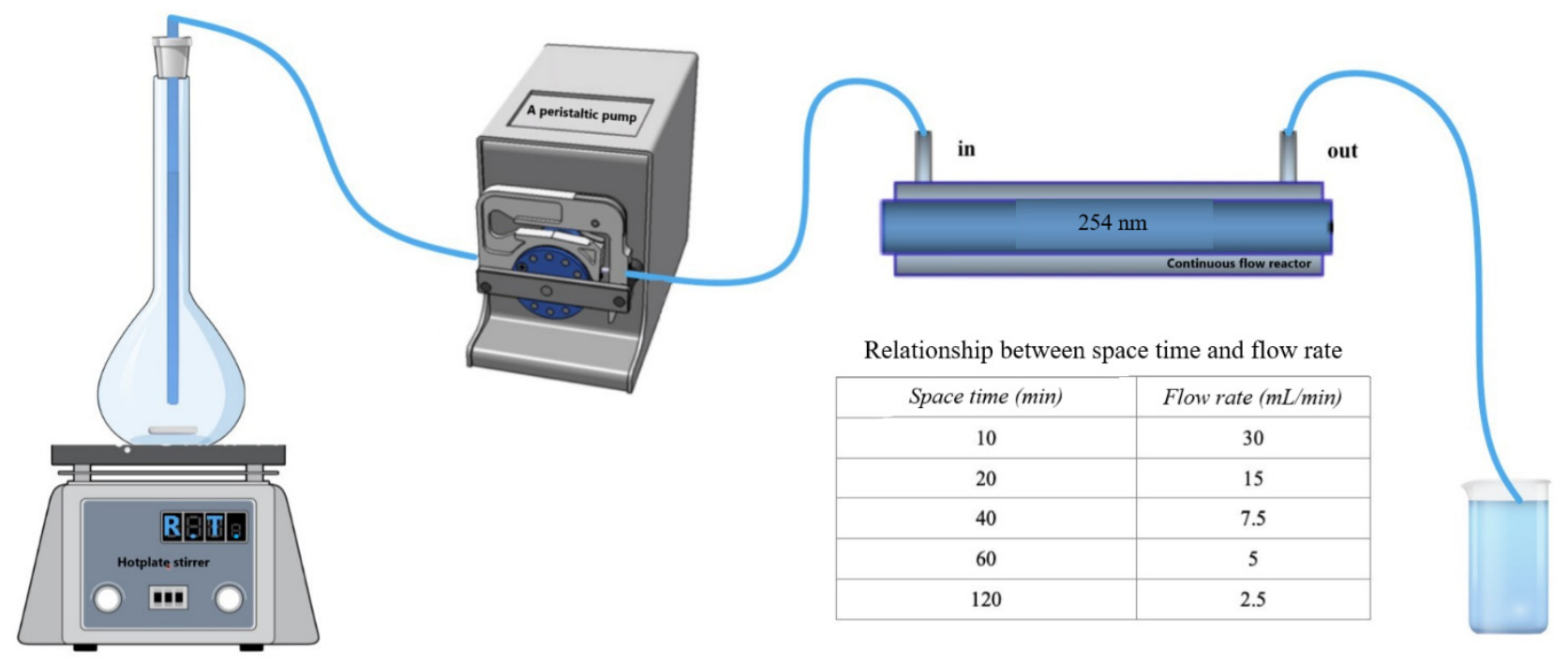

Figure 1. Experimental setup for the continuous flow photodegradation of 4-t-BP.

\subsection{Analytical Methods}

The concentration of 4-t-BP was determined using an Agilent 1290 Infinity II high performance liquid chromatography (HPLC) unit equipped with a UV detector. The SB-C8 analytical column $(2.1 \times 100 \mathrm{~mm}, 1.8 \mu \mathrm{m})$ was operated at $25^{\circ} \mathrm{C}$. In a typical run, a sample of $1 \mu \mathrm{L}$ was injected and the detection wavelength of $4-\mathrm{t}-\mathrm{BP}$ was set at $283 \mathrm{~nm}$. A mixture of $50 \% \mathrm{MeOH}$ and $50 \%$ ultrapure water was used as the mobile phase to elute the analytes at a flow rate of $0.4 \mathrm{~mL} / \mathrm{min}$.

TOC removal was determined by measuring the TOC in liquid samples by means of Multi N/C 3100, Analytic Jena AG Corporation (Jena, Germany). The pH of solutions was monitored using a Multi 9310 IDS meter.

\section{Results and Discussion}

\subsection{UV-Photolysis}

In order to gain insights into the performance of various UV-activated processes in continuous flow mode, a series of experiments in the absence of any catalyst and oxidant was performed by varying the space time (10, 20 40, 60 and $120 \mathrm{~min})$. The degradation of 4-t-BP steadily increased from 51.3 to $89.3 \%$ with the increase in space time from 10 to $120 \mathrm{~min}$ (Figure 2A). On the other hand, TOC removal did not significantly increase with increasing the space time above $20 \mathrm{~min}$ and the values observed were considerably 
lower than the corresponding values for 4-t-BP degradation (Figure 2B). The increase in space time promotes both the formation of more reactive species and the contact between produced reactive species and pollutants, which, in turn, leads to higher degradation efficiencies. However, the TOC removal is not promoted to the same extent, as UV-photolysis alone cannot completely mineralize organic carbon [41-43]. For example, Wu et al. [13] achieved $60 \%$ 4-t-BP degradation after $300 \mathrm{~min}$ of $254 \mathrm{~nm}$ UV irradiation and observed the generation of several by-products, including 4-tert-butylcatechol, 4-tert-Butylphenol and 1-tert-butyl-2-methoxy-4-methylbenzene as an impurity. The results indicated that major degradation products of 4-t-BP were 4-tert-butylcatechol and 4-tert-Butylphenol dimer. Such intermediates were also detected in the UV $(254 \mathrm{~nm}) / \mathrm{H}_{2} \mathrm{O}_{2}$ system and prolongation of the process time to $16 \mathrm{~h}$ resulted in only $29 \%$ of TOC removal, confirming the persistent nature of generated by-products to mineralization.

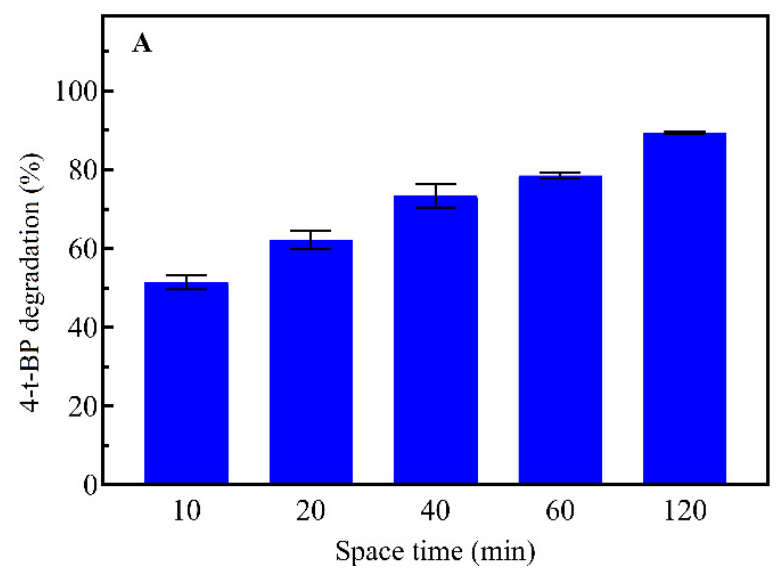

Figure 2. 4-t-BP degradation (A) and TOC removal (B) as a function of space time in the UV-photolysis.

\section{2. $\mathrm{UV} / \mathrm{H}_{2} \mathrm{O}_{2}$}

Subsequently, the $\mathrm{UV} / \mathrm{H}_{2} \mathrm{O}_{2}$ process' efficiency was examined by varying the initial concentration of hydrogen peroxide $(88.3 \mathrm{mg} / \mathrm{L}, 176.6 \mathrm{mg} / \mathrm{L}$ and $264 \mathrm{mg} / \mathrm{L})$ and space time values (10, 20 40, 60 and $120 \mathrm{~min})$. The results obtained are shown in Figure 3 and agree with previous studies $[12,21]$. The $\mathrm{UV} / \mathrm{H}_{2} \mathrm{O}_{2}$ process proceeds via direct photolysis and the formation of $\cdot \mathrm{OH}$ radicals that decompose most organic compounds without discrimination. Specifically, 93.34\% of 4-t-BP degradation was observed after $10 \mathrm{~min}$. This is due to the formation of sufficient amounts of hydroxyl radicals via the decomposition of $\mathrm{H}_{2} \mathrm{O}_{2}[44,45]$.

$$
\begin{gathered}
\mathrm{H}_{2} \mathrm{O}_{2}+\mathrm{hv} \rightarrow 2 \cdot \mathrm{OH} \\
\cdot \mathrm{OH}+4-\mathrm{t}-\mathrm{BP} \rightarrow \text { degradation products }
\end{gathered}
$$

As depicted in Figure 3A, degradation efficiency was not considerably affected by $\mathrm{H}_{2} \mathrm{O}_{2}$ concentration and space time. The concentration of $176.6 \mathrm{mg} / \mathrm{L}$ of $\mathrm{H}_{2} \mathrm{O}_{2}$ seemed to be the most beneficial one in terms of 4-t-BP degradation. Excessive doses of $\mathrm{H}_{2} \mathrm{O}_{2}$ beyond a certain value may have an inhibitory effect $[46,47]$ through the initiation of propagation reactions that form perhydroxyl radicals $\left(\mathrm{HO}_{2} \cdot\right)$, which are much less reactive than hydroxyl ones [48]. The detailed mechanism [49,50] is as follows (Equations (3)-(6)):

$$
\begin{gathered}
\cdot \mathrm{OH}+\mathrm{H}_{2} \mathrm{O}_{2} \rightarrow \mathrm{HO}_{2} \cdot+\mathrm{H}_{2} \mathrm{O} \\
\mathrm{HO}_{2} \cdot+\mathrm{H}_{2} \mathrm{O}_{2} \rightarrow \cdot \mathrm{OH}+\mathrm{H}_{2} \mathrm{O}+\mathrm{O}_{2} \\
\mathrm{HO}_{2} \cdot+\mathrm{HO}_{2}^{-} \rightarrow \cdot \mathrm{OH}+\mathrm{HO}^{-}+\mathrm{O}_{2} \\
\cdot \mathrm{OH}+\mathrm{HO}_{2} \cdot \rightarrow \mathrm{H}_{2} \mathrm{O}+\mathrm{O}_{2}
\end{gathered}
$$


Similar observations were made through TOC removal measurements. As a result, the values of $\left[\mathrm{H}_{2} \mathrm{O}_{2}\right]_{\mathrm{o}}=176.6 \mathrm{mg} / \mathrm{L}$ and space time $=60 \mathrm{~min}$ were selected as the desired conditions for further experiments.
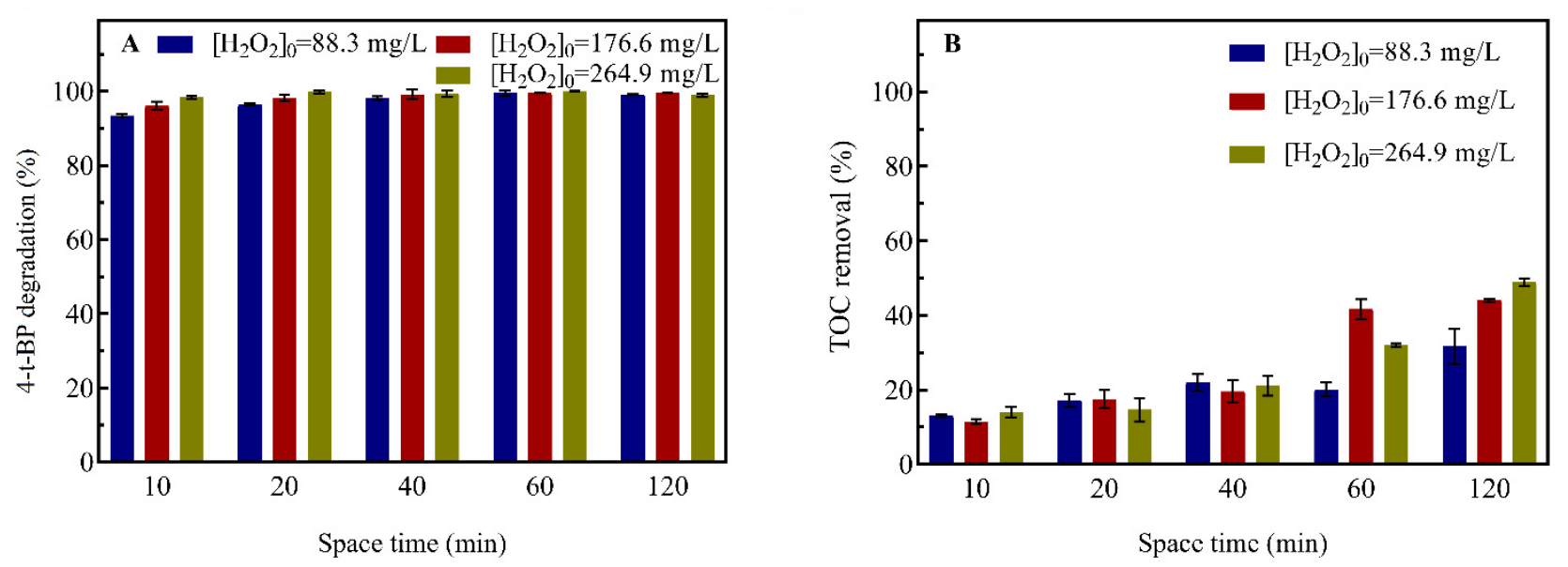

Figure 3. 4-t-BP degradation (A) and TOC removal (B) as a function of space time in the $\mathrm{UV} / \mathrm{H}_{2} \mathrm{O}_{2}$.

The maximum TOC removal corresponding to $48.8 \%$ was achieved by applying $\left[\mathrm{H}_{2} \mathrm{O}_{2}\right]_{\mathrm{o}}=264.9 \mathrm{mg} / \mathrm{L}$ and space time $=120 \mathrm{~min}$. The increase in TOC removal in the $\mathrm{UV} / \mathrm{H}_{2} \mathrm{O}_{2}$ system in comparison to UV-photolysis could be associated with the generation of both aromatic (4-tert-butylcatechol, 4-tert-Butylphenol and 1-tert-butyl-2-methoxy-4methylbenzene and hydroquinone) and non-aromatic products ((E)-2-Nonen-1-ol, trans-2Decenol and (E)-2-Dodecen-1-al), where the latter are the result of a benzene ring fracturing process [13].

\section{3. $\mathrm{UV} / \mathrm{Fe}^{2+} / \mathrm{H}_{2} \mathrm{O}_{2}$ and $\mathrm{UV} / \mathrm{Fe}^{3+} / \mathrm{H}_{2} \mathrm{O}_{2}$}

The effect of the presence of $\mathrm{Fe}^{3+}$ and $\mathrm{Fe}^{2+}$ ions on 4-t-BP degradation was also evaluated. The initial concentration of iron ions used was $5 \mathrm{mg} / \mathrm{L}$. The reaction between iron and $\mathrm{H}_{2} \mathrm{O}_{2}$ under $\mathrm{UV}$ light promotes the formation of $\mathrm{OH}$ [51] to effectively oxidize pollutants through Equations (7)-(14):

$$
\begin{gathered}
\mathrm{Fe}^{2+}+\mathrm{H}_{2} \mathrm{O}_{2} \rightarrow \mathrm{Fe}^{3+}+\cdot \mathrm{OH}+\mathrm{OH}^{-} \\
\mathrm{Fe}^{3+}+\mathrm{H}_{2} \mathrm{O}_{2} \rightarrow \mathrm{Fe}^{2+}+\mathrm{HO}_{2} \cdot+\mathrm{H}^{+} \\
\cdot \mathrm{OH}+\mathrm{H}_{2} \mathrm{O}_{2} \rightarrow \mathrm{HO}_{2} \cdot+\mathrm{H}_{2} \mathrm{O} \\
\mathrm{Fe}^{2+}+\cdot \mathrm{OH} \rightarrow \mathrm{Fe}^{3+}+\mathrm{OH}^{-} \\
\mathrm{Fe}^{3+}+\mathrm{HO}_{2} \cdot \rightarrow \mathrm{Fe}^{2+}+\mathrm{O}_{2}+\mathrm{H}^{+} \\
\cdot \mathrm{OH}+\cdot \mathrm{OH} \rightarrow \mathrm{H}_{2} \mathrm{O}_{2} \\
4-\mathrm{t}-\mathrm{BP}+\cdot \mathrm{OH} \rightarrow \text { Intermediates } \\
\text { Intermediates }+\cdot \mathrm{OH} \rightarrow \mathrm{CO}_{2}+\mathrm{H}_{2} \mathrm{O}
\end{gathered}
$$

Figure $4 \mathrm{~A}$ shows a similar oxidation performance for $\mathrm{Fe}^{2+} / \mathrm{UV} / \mathrm{H}_{2} \mathrm{O}_{2}$ towards 4-t-BP degradation as in $\mathrm{UV} / \mathrm{H}_{2} \mathrm{O}_{2}$ after 60 min of irradiation. The efficiency of $\mathrm{Fe}^{3+} / \mathrm{UV} / \mathrm{H}_{2} \mathrm{O}_{2}$ was slightly lower. In contrast, an enhanced TOC removal (Figure 4B) was observed for the $\mathrm{Fe}^{3+} / \mathrm{UV} / \mathrm{H}_{2} \mathrm{O}_{2}$ process, indicating a favorable $\mathrm{Fe}^{3+}$ contribution to the catalytic decomposition of $\mathrm{H}_{2} \mathrm{O}_{2}$ [52]. This can be attributed to a synergistic effect between $\mathrm{Fe}^{3+}$, $\mathrm{UV}$ and $\mathrm{H}_{2} \mathrm{O}_{2}$. TOC removal efficiencies followed the following order: $\mathrm{Fe}^{3+} / \mathrm{UV} / \mathrm{H}_{2} \mathrm{O}_{2}>$ $\mathrm{Fe}^{2+} / \mathrm{UV} / \mathrm{H}_{2} \mathrm{O}_{2}>\mathrm{UV} / \mathrm{H}_{2} \mathrm{O}_{2}$. 

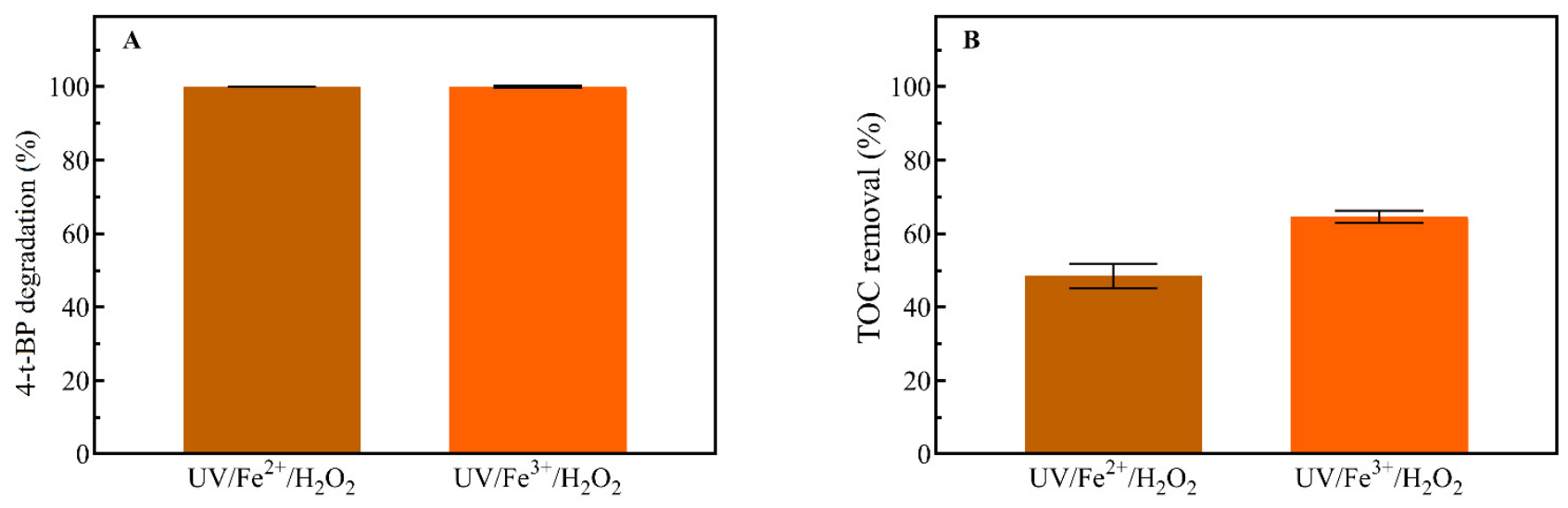

Figure 4. 4-t-BP degradation (A) and TOC removal (B) in the $\mathrm{Fe}^{2+} / \mathrm{UV} / \mathrm{H}_{2} \mathrm{O}_{2}$ and $\mathrm{Fe}^{3+} / \mathrm{UV} / \mathrm{H}_{2} \mathrm{O}_{2}$ at optimal conditions (conditions: space time $=60 \mathrm{~min}, 5 \mathrm{mg} / \mathrm{L}$ of catalyst, $\left[\mathrm{H}_{2} \mathrm{O}_{2}\right]=176.6 \mathrm{mg} / \mathrm{L}$ ).

\section{4. $\mathrm{UV} / \mathrm{TiO}_{2}$ and $\mathrm{UV} / \mathrm{Fe}-\mathrm{TiO}_{2}$}

The photocatalytic behavior of undoped $\mathrm{TiO}_{2}$ and $\mathrm{Fe}$-doped $\mathrm{TiO}_{2}$ was examined for 4-t-BP degradation (Figure 5). The photocatalytic activity of $\mathrm{Fe}^{-\mathrm{TiO}_{2}}$ relies on the dopant concentration [53-59]. $\mathrm{Fe}-\mathrm{TiO}_{2}$ at a mass ratio of $4 \%$ was selected as based on previously reported results $[60,61]$.
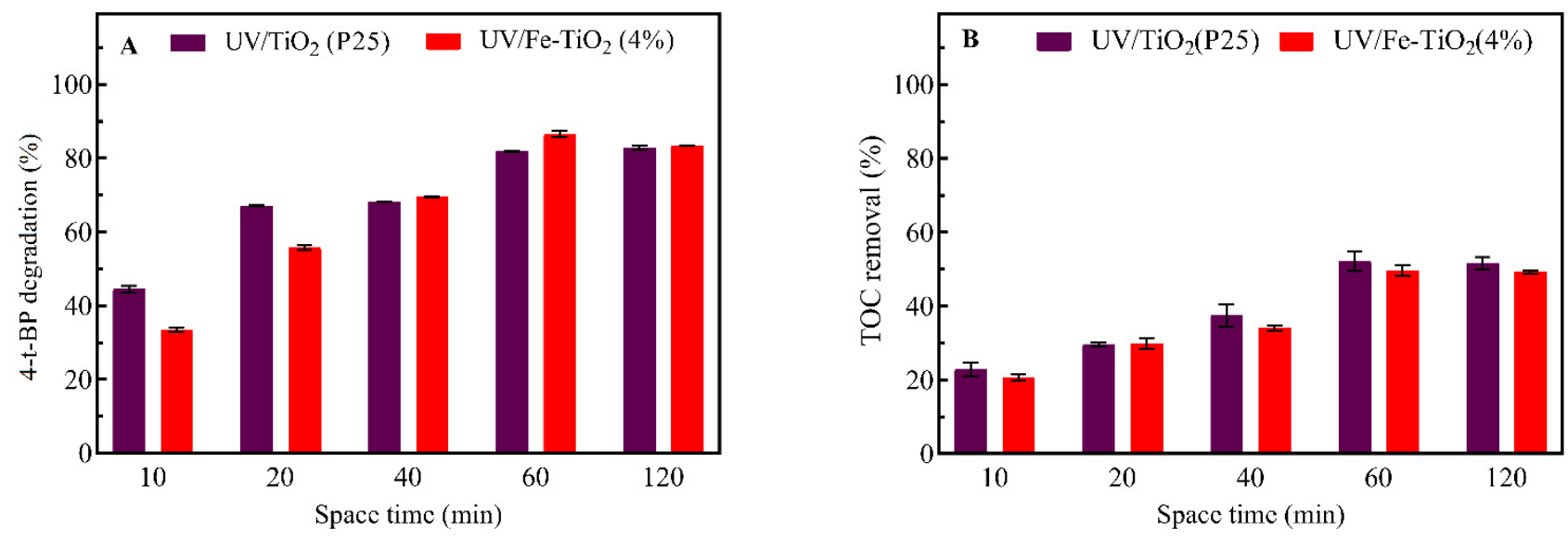

Figure 5. 4-t-BP degradation (A) and TOC removal (B) as a function of space time in the $\mathrm{UV} / \mathrm{TiO}_{2}$ and $\mathrm{UV} / \mathrm{Fe}-\mathrm{TiO}_{2}$.

As shown in Figure 5, 4-t-BP and TOC removals were apparently increased with an increasing space time from $10 \mathrm{~min}$ to $60 \mathrm{~min}$ for both $\mathrm{TiO}_{2}$ and $\mathrm{Fe}-\mathrm{TiO}_{2}$, indicating substantial impact of space time on the performance of the systems. However, increasing space time from $60 \mathrm{~min}$ to $120 \mathrm{~min}$ resulted in apparently lower 4-t-BP degradation and TOC removal. Compared to pure $\mathrm{TiO}_{2}$, the incorporation of iron particles slightly induced the degradation of 4 -t-BP, degrading $87 \%$ after $60 \mathrm{~min}$ instead of $82 \%$. This can be attributed to the retardation of the electron-hole pairs recombination [62]. It is noteworthy to mention that at lower space time (10 and $20 \mathrm{~min}$ ), the performance of $\mathrm{TiO}_{2}$ exceeded $\mathrm{Fe}-\mathrm{TiO}_{2}$, reaching $44.48 \%$ and $67 \%$ of 4 -t-BP degradation in comparison to $33.41 \%$ and $55.79 \%$, respectively. Comparatively, further increases in space time to $40 \mathrm{~min}$ and $60 \mathrm{~min}$ resulted in surpassed catalytic activity of $\mathrm{Fe}-\mathrm{TiO}_{2}$ over $\mathrm{TiO}_{2}$.

\subsection{Comparison of $U V$-Induced Processes}

In order to compare the performance of UV-based processes, 4-t-BP degradation and TOC removal were plotted at the space time of $60 \mathrm{~min}$. As observed in Figure 6A, the highest 4-t-BP degradation was achieved in the presence of $\mathrm{H}_{2} \mathrm{O}_{2}$ with the values ranging 
from $99.45 \%$ to $100 \%$ and followed the order of $\mathrm{UV} / \mathrm{H}_{2} \mathrm{O}_{2}(264.9 \mathrm{mg} / \mathrm{L}) \approx \mathrm{UV} / \mathrm{Fe}^{2+} / \mathrm{H}_{2} \mathrm{O}_{2}$ $>\mathrm{UV} / \mathrm{Fe}^{3+} / \mathrm{H}_{2} \mathrm{O}_{2}>\mathrm{UV} / \mathrm{H}_{2} \mathrm{O}_{2}(176.6 \mathrm{mg} / \mathrm{L})>\mathrm{UV} / \mathrm{H}_{2} \mathrm{O}_{2}(88.3 \mathrm{mg} / \mathrm{L})>\mathrm{UV} / \mathrm{Fe}-\mathrm{TiO}_{2}>$ $\mathrm{UV} / \mathrm{TiO}_{2}>\mathrm{UV}$ only. Since the addition of $\mathrm{H}_{2} \mathrm{O}_{2}$ yield in a formation of higher amounts of hydroxyl radicals, the observed enhancement was expected. On the other hand, $\mathrm{H}_{2} \mathrm{O}_{2}$ concentration increase in $\mathrm{UV} / \mathrm{H}_{2} \mathrm{O}_{2}$ system had an almost negligible effect on the degradation. As for the heterogeneous AOPs, the removal efficiency of 4 -t-BP was $81.8 \%$ and $86.5 \%$ with $\mathrm{TiO}_{2}$ and $\mathrm{Fe}-\mathrm{TiO}_{2}$ in the concentration of $200 \mathrm{mg} / \mathrm{L}$, which indicates slight increased degradation of 4-t-BP than that of UV treatment only. It is worth mentioning that combination of continuous flow and $\mathrm{UV} / \mathrm{Fe}-\mathrm{TiO}_{2}$ process contributed to the improvement of photo-oxidation reaction, while in a similar study [21] under batch-operated mode, the removal of 4-t-BP was higher by means of commercial $\mathrm{TiO}_{2}$ than that of $\mathrm{Fe}-\mathrm{TiO}_{2}$.
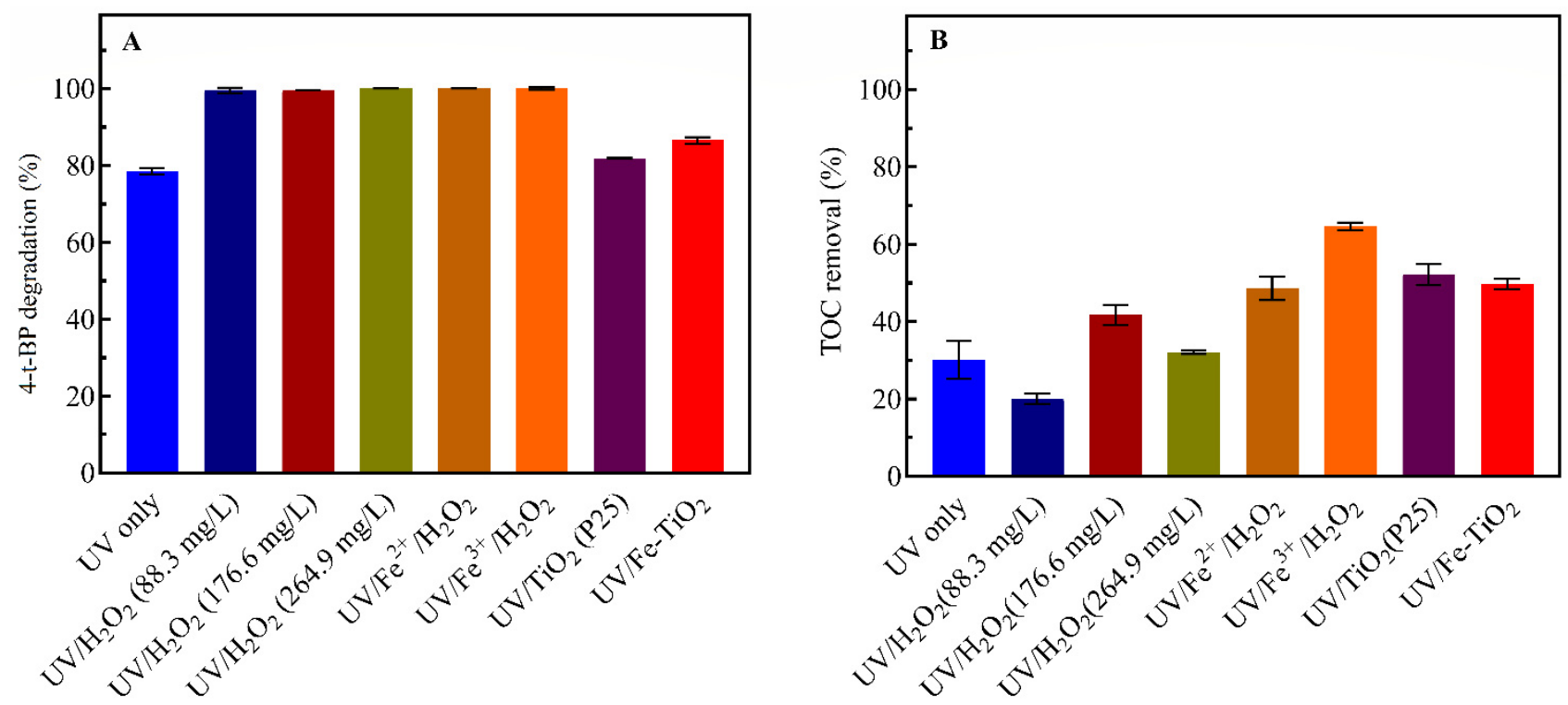

Figure 6. 4-t-BP degradation (A) and TOC removal (B) of various UV-induced AOPs at optimum space time $=60 \mathrm{~min}$.

Although 4-t-BP was largely degraded by almost all applied $\mathrm{H}_{2} \mathrm{O}_{2}$ concentrations after $60 \mathrm{~min}$, the TOC removal varied from 20.05 to $41.66 \%$. UV treatment alone did not provide significant levels of TOC removal, while removals around $50 \%$ were achieved within $60 \mathrm{~min}$ in the presence of heterogeneous photocatalysts $\left(\mathrm{Fe}-\mathrm{TiO}_{2}\right.$ or $\left.\mathrm{TiO}_{2}\right)$. Despite the low amount of $\mathrm{Fe}^{3+}$ added, its combination with $\mathrm{H}_{2} \mathrm{O}_{2}$ and $\mathrm{UV}$ led to the highest TOC removal (65\%). The rank of TOC removal efficiency followed the order of $\mathrm{UV} / \mathrm{Fe}^{3+} / \mathrm{H}_{2} \mathrm{O}_{2}>\mathrm{UV} / \mathrm{TiO}_{2}>$ $\mathrm{UV} / \mathrm{Fe}-\mathrm{TiO}_{2}>\mathrm{UV} / \mathrm{Fe}^{2+} / \mathrm{H}_{2} \mathrm{O}_{2}>\mathrm{UV} / \mathrm{H}_{2} \mathrm{O}_{2}(176.6 \mathrm{mg} / \mathrm{L})>\mathrm{UV} / \mathrm{H}_{2} \mathrm{O}_{2}(264.9 \mathrm{mg} / \mathrm{L})>\mathrm{UV}$ only $>\mathrm{UV} / \mathrm{H}_{2} \mathrm{O}_{2}(88.3 \mathrm{mg} / \mathrm{L})$.

\section{Conclusions}

In the present work, various continuous-flow UV-mediated AOPs were used for the degradation of 4-t-BP and TOC removal in water. The results showed that $93.34 \% 4-\mathrm{t}-\mathrm{BP}$ degradation could be achieved at relatively low space time of 10 min in the $\mathrm{UV} / \mathrm{H}_{2} \mathrm{O}_{2}$ system with oxidant concentration of $88.3 \mathrm{mg} / \mathrm{L}$. The presence of $\mathrm{H}_{2} \mathrm{O}_{2}$ contributes to the highest degradation efficiencies, making homogeneous $\mathrm{AOPs}\left(\mathrm{UV} / \mathrm{H}_{2} \mathrm{O}_{2}, \mathrm{UV} / \mathrm{Fe}^{2+} / \mathrm{H}_{2} \mathrm{O}_{2}\right.$ and $\mathrm{UV} / \mathrm{Fe}^{3+} / \mathrm{H}_{2} \mathrm{O}_{2}$ ) attractive for the removal of 4-t-BP.

Generally, flow rate had a positive effect on degradation efficiency, where optimal time to achieve the highest removal for most of the studied processes was found to be $60 \mathrm{~min}$. As a result, the degradation performance improvement of $\mathrm{UV}, \mathrm{UV} / \mathrm{TiO}_{2}$ and $\mathrm{UV} / \mathrm{Fe}-\mathrm{TiO}_{2}$ was observed with the increase in space time. Moreover, the photocatalytic activity for TOC removal ability was also evaluated. Higher TOC removal efficiencies were observed in the catalyst-assisted systems. Approximately $65 \%$ of TOC abatement in less 
than 60 min was achieved under $\mathrm{UV} / \mathrm{Fe}^{3+} / \mathrm{H}_{2} \mathrm{O}_{2}$ treatment at an optimized concentration of $\mathrm{H}_{2} \mathrm{O}_{2}(176.6 \mathrm{mg} / \mathrm{L})$, probably because of the achieved synergistic effect between oxidant, catalyst, UV exposure and flow system. Overall, the findings propose attractive applications of continuous flow treatment systems for efficient water remediation contaminated with 4-t-BP.

Author Contributions: Conceptualization, S.M. and S.G.P.; methodology, S.M. and S.G.P.; validation, S.G.P.; investigation, S.M.; resources, S.G.P.; writing—original draft preparation, S.M.; writingreview and editing, S.M. and S.G.P.; supervision, S.G.P.; project administration, S.G.P.; funding acquisition, S.G.P. All authors have read and agreed to the published version of the manuscript.

Funding: This research was funded by the Nazarbayev University project "Noble metals nanocomposites hyper-activity in heterogeneous non-catalytic and catalytic reactions", Faculty development competitive research grants program for 2019-2021, Grant Number 110119FD4536.

Institutional Review Board Statement: Not applicable.

Informed Consent Statement: Not applicable.

Data Availability Statement: Not applicable.

Acknowledgments: The authors acknowledge funding support from Nazarbayev University. The technical support of the Core Facilities of Nazarbayev University is greatly acknowledged.

Conflicts of Interest: The authors declare no conflict of interest. The funders had no role in the design of the study; in the collection, analyses, or interpretation of data; in the writing of the manuscript, or in the decision to publish the results.

\section{References}

1. Heemken, O.P.; Reincke, H.; Stachel, B.; Theobald, N. The Occurrence of Xenoestrogens in the Elbe River and the North Sea. Chemosphere 2001, 45, 245-259. [CrossRef]

2. Inoue, K.; Yoshie, Y.; Kondo, S.; Yoshimura, Y.; Nakazawa, H. Determination of Phenolic Xenoestrogens in Water by Liquid Chromatography with Coulometric-Array Detection. J. Chromatogr. A 2002, 946, 291-294. [CrossRef]

3. Koh, C.-H.; Khim, J.S.; Villeneuve, D.L.; Kannan, K.; Giesy, J.P. Characterization of Trace Organic Contaminants in Marine Sediment from Yeongil Bay, Korea: 1. Instrumental Analyses. Environ. Pollut. 2006, 142, 39-47. [CrossRef] [PubMed]

4. Chang, H.-S.; Choo, K.-H.; Lee, B.; Choi, S.-J. The Methods of Identification, Analysis, and Removal of Endocrine Disrupting Compounds (EDCs) in Water. J. Hazard. Mater. 2009, 172, 1-12. [CrossRef]

5. Tang, Y.; Yin, M.; Yang, W.; Li, H.; Zhong, Y.; Mo, L.; Liang, Y.; Ma, X.; Sun, X. Emerging Pollutants in Water Environment: Occurrence, Monitoring, Fate, and Risk Assessment. Water Environ. Res. Res. Publ. Water Environ. Fed. 2019, 91, 984-991. [CrossRef]

6. Annamalai, J.; Namasivayam, V. Endocrine Disrupting Chemicals in the Atmosphere: Their Effects on Humans and Wildlife. Environ. Int. 2015, 76, 78-97. [CrossRef]

7. Acir, I.-H.; Guenther, K. Endocrine-Disrupting Metabolites of Alkylphenol Ethoxylates-A Critical Review of Analytical Methods, Environmental Occurrences, Toxicity, and Regulation. Sci. Total Environ. 2018, 635, 1530-1546. [CrossRef] [PubMed]

8. Balaguer, P.; Delfosse, V.; Grimaldi, M.; Bourguet, W. Structural and Functional Evidences for the Interactions between Nuclear Hormone Receptors and Endocrine Disruptors at Low Doses. Comptes Rendus Biol. 2017, 340, 414-420. [CrossRef] [PubMed]

9. Toyama, T.; Momotani, N.; Ogata, Y.; Miyamori, Y.; Inoue, D.; Sei, K.; Mori, K.; Kikuchi, S.; Ike, M. Isolation and Characterization of 4-tert-Butylphenol-Utilizing Sphingobium Fuliginis Strains from Phragmites Australis Rhizosphere Sediment. Appl. Environ. Microbiol. 2010, 76, 6733-6740. [CrossRef]

10. Webster, F.; Gagné, M.; Patlewicz, G.; Pradeep, P.; Trefiak, N.; Judson, R.S.; Barton-Maclaren, T.S. Predicting Estrogen Receptor Activation by a Group of Substituted Phenols: An Integrated Approach to Testing and Assessment Case Study. Regul. Toxicol. Pharmacol. 2019, 106, 278-291. [CrossRef] [PubMed]

11. Wirasnita, R.; Mori, K.; Toyama, T. Effect of Activated Carbon on Removal of Four Phenolic Endocrine-Disrupting Compounds, Bisphenol A, Bisphenol F, Bisphenol S, and 4-tert-Butylphenol in Constructed Wetlands. Chemosphere 2018, 210, 717-725. [CrossRef] [PubMed]

12. Wu, Y.; Zhu, X.; Chen, H.; Dong, W.; Zhao, J. Photodegradation of 4-tert-Butylphenol in Aqueous Solution by UV-C, UV/ $\mathrm{H}_{2} \mathrm{O}_{2}$ and $\mathrm{UV} / \mathrm{S}_{2} \mathrm{O}_{8}{ }^{2-}$ System. J. Environ. Sci. Health Part A 2016, 51, 440-445. [CrossRef]

13. Wu, Y.; Shi, J.; Chen, H.; Zhao, J.; Dong, W. Aqueous Photodegradation of 4-tert-Butylphenol: By-Products, Degradation Pathway and Theoretical Calculation Assessment. Sci. Total Environ. 2016, 566-567, 86-92. [CrossRef]

14. Olsen, C.M.; Meussen-Elholm, E.T.M.; Hongslo, J.K.; Stenersen, J.; Tollefsen, K.-E. Estrogenic Effects of Environmental Chemicals: An Interspecies Comparison. Comp. Biochem. Physiol. Part C Toxicol. Pharmacol. 2005, 141, 267-274. [CrossRef] [PubMed] 
15. Barse, A.V.; Chakrabarti, T.; Ghosh, T.; Pal, A.; Jadhao, S. One-Tenth Dose of LC50 of 4-tert-Butylphenol Causes Endocrine Disruption and Metabolic Changes in Cyprinus Carpio. Pestic. Biochem. Physiol. 2006, 86, 172-179. [CrossRef]

16. Meier, S.; Andersen, T.E.; Norberg, B.; Thorsen, A.; Taranger, G.L.; Kjesbu, O.S.; Dale, R.; Morton, H.C.; Klungsøyr, J.; Svardal, A. Effects of Alkylphenols on the Reproductive System of Atlantic Cod (Gadus Morhua). Aquat. Toxicol. 2007, 81, 207-218. [CrossRef]

17. EUR-Lex-32019D1194-EN-EUR-Lex. Available online: https://eur-lex.europa.eu/eli/dec_impl/2019/1194/oj (accessed on 4 November 2021).

18. Fan, D.; Liu, J.; Wang, L.; Yang, X.; Zhang, S.; Zhang, Y.; Shi, L. Development of Quantitative Structure-Activity Relationship Models for Predicting Chronic Toxicity of Substituted Benzenes to Daphnia Magna. Bull. Environ. Contam. Toxicol. 2016, 96, 664-670. [CrossRef]

19. Wang, L.; Liu, J.; Liu, J.; Shi, L.; Wang, Z. Application of Microcosm and Species Sensitivity Distribution Approaches in the Ecological Hazard Assessment of 4-tert-Butylphenol. Chem. Ecol. 2017, 34, 108-125. [CrossRef]

20. Janousek, R.M.; Müller, J.; Knepper, T.P. Combined Study of Source, Environmental Monitoring and Fate of Branched Alkylphenols: The Chain Length Matters. Chemosphere 2020, 241, 124950. [CrossRef] [PubMed]

21. Makhatova, A.; Ulykbanova, G.; Sadyk, S.; Sarsenbay, K.; Atabaev, T.S.; Inglezakis, V.J.; Poulopoulos, S.G. Degradation and Mineralization of 4-tert-Butylphenol in Water Using Fe-Doped $\mathrm{TiO}_{2}$ Catalysts. Sci. Rep. 2019, 9, 19284. [CrossRef]

22. Dan, A.; Fujii, D.; Soda, S.; Machimura, T.; Ike, M. Removal of Phenol, Bisphenol A, and 4-tert-Butylphenol from Synthetic Landfill Leachate by Vertical Flow Constructed Wetlands. Sci. Total Environ. 2017, 578, 566-576. [CrossRef]

23. Nguyen, L.N.; Hai, F.I.; Yang, S.; Kang, J.; Leusch, F.D.L.; Roddick, F.; Price, W.E.; Nghiem, L.D. Removal of Pharmaceuticals, Steroid Hormones, Phytoestrogens, UV-Filters, Industrial Chemicals and Pesticides by Trametes Versicolor: Role of Biosorption and Biodegradation. Int. Biodeterior. Biodegrad. 2014, 88, 169-175. [CrossRef]

24. Nguyen, L.N.; Hai, F.I.; Price, W.E.; Kang, J.; Leusch, F.D.L.; Roddick, F.; van de Merwe, J.P.; Magram, S.F.; Nghiem, L.D. Degradation of a Broad Spectrum of Trace Organic Contaminants by an Enzymatic Membrane Reactor: Complementary Role of Membrane Retention and Enzymatic Degradation. Int. Biodeterior. Biodegrad. 2015, 99, 115-122. [CrossRef]

25. Ogata, Y.; Toyama, T.; Yu, N.; Wang, X.; Sei, K.; Ike, M. Occurrence of 4-tert-Butylphenol (4-t-BP) Biodegradation in an Aquatic Sample Caused by the Presence of Spirodela Polyrrhiza and Isolation of a 4-t-BP-Utilizing Bacterium. Biodegradation 2013, 24, 191-202. [CrossRef] [PubMed]

26. Hong, Y.; Li, C.; Zhang, G.; Meng, Y.; Yin, B.; Zhao, Y.; Shi, W. Efficient and Stable $\mathrm{Nb}_{2} \mathrm{O}_{5}$ Modified G-C $_{3} \mathrm{~N}_{4}$ Photocatalyst for Removal of Antibiotic Pollutant. Chem. Eng. J. 2016, 299, 74-84. [CrossRef]

27. Lee, Y.; von Gunten, U. Oxidative Transformation of Micropollutants during Municipal Wastewater Treatment: Comparison of Kinetic Aspects of Selective (Chlorine, Chlorine Dioxide, FerrateVI, and Ozone) and Non-Selective Oxidants (Hydroxyl Radical). Water Res. 2010, 44, 555-566. [CrossRef]

28. Muruganandham, M.; Suri, R.; Jafari, S.; Sillanpää, M.; Lee, G.-J.; Wu, J.; Swaminathan, M. Recent Developments in Homogeneous Advanced Oxidation Processes for Water and Wastewater Treatment. Int. J. Photoenergy 2014, 2014, 821674. [CrossRef]

29. Wu, Y.; Brigante, M.; Dong, W.; Claire, P.; Mailhot, G. Toward a Better Understanding of Fe(III)-EDDS Photochemistry: Theoretical Stability Calculation and Experimental Investigation of 4-tert-Butylphenol Degradation. J. Phys. Chem. A 2013, 118, 396-403. [CrossRef]

30. Wu, Y.; Prulho, R.; Brigante, M.; Dong, W.; Hanna, K.; Mailhot, G. Activation of Persulfate by Fe(III) Species: Implications for 4-tert-Butylphenol Degradation. J. Hazard. Mater. 2016, 322, 380-386. [CrossRef]

31. Xiao, X.; Xing, C.; He, G.; Zuo, X.; Nan, J.; Wang, L. Solvothermal Synthesis of Novel Hierarchical Bi ${ }_{4} \mathrm{O}_{5} \mathrm{I}_{2} \mathrm{Nanoflakes} \mathrm{with}$ Highly Visible Light Photocatalytic Performance for the Degradation of 4-tert-Butylphenol. Appl. Catal. B Environ. 2014, 148-149, 154-163. [CrossRef]

32. Chen, Y.; Ye, J.; Li, C.; Zhou, P.; Liu, J.; Ou, H. Degradation of $1 \mathrm{H}$-Benzotriazole by $\mathrm{UV} / \mathrm{H}_{2} \mathrm{O}_{2}$ and UV/TiO 2 : Kinetics, Mechanisms, Products and Toxicology. Environ. Sci. Water Res. Technol. 2018, 4, 1282-1294. [CrossRef]

33. Peternel, I.T.; Koprivanac, N.; Božić, A.M.L.; Kušić, H.M. Comparative Study of UV/TiO, UV/ZnO and Photo-Fenton Processes for the Organic Reactive Dye Degradation in Aqueous Solution. J. Hazard. Mater. 2007, 148, 477-484. [CrossRef] [PubMed]

34. Martínez-Costa, J.I.; Rivera-Utrilla, J.; Leyva-Ramos, R.; Sánchez-Polo, M.; Velo-Gala, I.; Mota, A.J. Individual and Simultaneous Degradation of the Antibiotics Sulfamethoxazole and Trimethoprim in Aqueous Solutions by Fenton, Fenton-like and PhotoFenton Processes Using Solar and UV Radiations. J. Photochem. Photobiol. Chem. 2018, 360, 95-108. [CrossRef]

35. Chang, S.; Yang, X.; Sang, Y.; Liu, H. Highly Efficient Photocatalysts and Continuous-Flow Photocatalytic Reactors for Degradation of Organic Pollutants in Wastewater. Chem. Asian J. 2016, 11, 2352-2371. [CrossRef] [PubMed]

36. Carbonaro, S.; Sugihara, M.N.; Strathmann, T.J. Continuous-Flow Photocatalytic Treatment of Pharmaceutical Micropollutants: Activity, Inhibition, and Deactivation of TiO2 Photocatalysts in Wastewater Effluent. Appl. Catal. B Environ. 2013, 129, 1-12. [CrossRef]

37. Petala, A.; Spyrou, D.; Frontistis, Z.; Mantzavinos, D.; Kondarides, D.I. Immobilized $\mathrm{Ag}_{3} \mathrm{PO}_{4}$ Photocatalyst for Micro-Pollutants Removal in a Continuous Flow Annular Photoreactor. Catal. Today 2019, 328, 223-229. [CrossRef]

38. Silva, C.P.; Oliveira, C.; Ribeiro, A.; Osório, N.; Otero, M.; Esteves, V.I.; Lima, D.L.D. Sulfamethoxazole Exposure to Simulated Solar Radiation under Continuous Flow Mode: Degradation and Antibacterial Activity. Chemosphere 2020, 238, 124613. [CrossRef] [PubMed] 
39. Shojaeimehr, T.; Tasbihi, M.; Acharjya, A.; Thomas, A.; Schomäcker, R.; Schwarze, M. Impact of Operating Conditions for the Continuous-Flow Degradation of Diclofenac with Immobilized Carbon Nitride Photocatalysts. J. Photochem. Photobiol. Chem. 2019, 388, 112182. [CrossRef]

40. Jaganathan, S.; Philip, L. Elimination of Pesticides and Their Formulation Products from Drinking Water Using Thin Film Continuous Photoreactor under Solar Radiation. Sol. Energy 2012, 86, 2735-2745. [CrossRef]

41. Piña-Pérez, Y.; Aguilar-Martínez, O.; Oros-Ruíz, S.; Gómez, R.; Tzompantzi, F. Commercial Aluminum Oxides with Different Crystalline Structures Efficient for the Mineralization of Phenolic Pollutants. J. Photochem. Photobiol. Chem. 2018, 353, 409-415. [CrossRef]

42. Chen, J.; He, Z.; Ji, Y.; Li, G.; An, T.; Choi, W. OH Radicals Determined Photocatalytic Degradation Mechanisms of Gaseous Styrene in $\mathrm{TiO}_{2}$ System under $254 \mathrm{Nm}$ versus $185 \mathrm{Nm}$ Irradiation: Combined Experimental and Theoretical Studies. Appl. Catal. B Environ. 2019, 257, 117912. [CrossRef]

43. Poulopoulos, S.G.; Yerkinova, A.; Ulykbanova, G.; Inglezakis, V.J. Photocatalytic Treatment of Organic Pollutants in a Synthetic Wastewater Using UV Light and Combinations of $\mathrm{TiO}_{2}, \mathrm{H}_{2} \mathrm{O}_{2}$ and $\mathrm{Fe}(\mathrm{III})$. PLoS ONE 2019, 14, e0216745. [CrossRef] [PubMed]

44. Ou, H.-S.; Ye, J.-S.; Ma, S.; Wei, C.-H.; Gao, N.-Y.; He, J. Degradation of Ciprofloxacin by UV and UV/ $\mathrm{H}_{2} \mathrm{O}_{2}$ via MultipleWavelength Ultraviolet Light-Emitting Diodes: Effectiveness, Intermediates and Antibacterial Activity. Chem. Eng. J. 2016, 289, 391-401. [CrossRef]

45. Zhang, Y.; Zhang, J.; Xiao, Y.; Chang, V.; Lim, T. Kinetic and Mechanistic Investigation of Azathioprine Degradation in Water by $\mathrm{UV}, \mathrm{UV} / \mathrm{H}_{2} \mathrm{O}_{2}$ and UV/Persulfate. Chem. Eng. J. 2016, 302, 526-534. [CrossRef]

46. Afzal, T.; Isa, M.H.; UI Mustafa, M.R. Removal of Organic Pollutants from Produced Water Using Fenton Oxidation. E3S Web Conf. 2018, 34, 02035. [CrossRef]

47. Daneshvar, N.; Salari, D.; Khataee, A.R. Photocatalytic Degradation of Azo Dye Acid Red 14 in Water on ZnO as an Alternative Catalyst to $\mathrm{TiO}_{2}$. J. Photochem. Photobiol. Chem. 2004, 162, 317-322. [CrossRef]

48. Watts, R.J.; Sarasa, J.; Loge, F.J.; Teel, A.L. Oxidative and Reductive Pathways in Manganese-Catalyzed Fenton's Reactions. J. Environ. Eng. 2005, 131, 158-164. [CrossRef]

49. Liu, X.; Liu, Y.; Lu, S.; Wang, Z.; Wang, Y.; Zhang, G.; Guo, X.; Guo, W.; Zhang, T.; Xi, B. Degradation Difference of Ofloxacin and Levofloxacin by UV/H2O2 and UV/PS (Persulfate): Efficiency, Factors and Mechanism. Chem. Eng. J. 2020, $385,123987$. [CrossRef]

50. Samarghandi, M.R.; Dargahi, A.; Zolghadr Nasab, H.; Ghahramani, E.; Salehi, S. Degradation of Azo Dye Acid Red 14 (AR14) from Aqueous Solution Using $\mathrm{H}_{2} \mathrm{O}_{2} /$ NZVI and $\mathrm{S}_{2} \mathrm{O}_{8}{ }^{2-} / \mathrm{NZVI}$ Processes in the Presence of UV Irradiation. Water Environ. Res. Res. Publ. Water Environ. Fed. 2020, 92, 1173-1183. [CrossRef]

51. Rivas, F.J.; Beltrán, F.J.; Frades, J.; Buxeda, P. Oxidation of P-Hydroxybenzoic Acid by Fenton's Reagent. Water Res. 2001, 35, 387-396. [CrossRef]

52. Augugliaro, V.; Litter, M.; Palmisano, L.; Soria, J. The Combination of Heterogeneous Photocatalysis with Chemical and Physical Operations: A Tool for Improving the Photoprocess Performance. J. Photochem. Photobiol. C Photochem. Rev. 2006, 7, 127-144. [CrossRef]

53. Hemmati Borji, S.; Nasseri, S.; Mahvi, A.H.; Nabizadeh, R.; Javadi, A.H. Investigation of Photocatalytic Degradation of Phenol by Fe(III)-Doped $\mathrm{TiO}_{2}$ and $\mathrm{TiO}_{2}$ Nanoparticles. J. Environ. Health Sci. Eng. 2014, 12, 101. [CrossRef] [PubMed]

54. JIménez, D.H.; Triviño, G.M.H.; Villaseñor, E.A.; Mesa, E.B.; Hernández, J.A.; Zepeda, T.A.; Zapata, R.B.; Arias, A.N.A. Phenol Photocatalytic Degradation over $\mathrm{Fe}-\mathrm{TiO}_{2}$ Materials Synthesized by Different Methods. Sci. Tech. 2019, 24, 523-531. [CrossRef]

55. Jamil, T.S.; Gad-Allah, T.A.; Ghaly, M.Y. Parametric Study on Phenol Photocatalytic Degradation under Pure Visible and Solar Irradiations by Fe-Doped $\mathrm{TiO}_{2}$. Desalination Water Treat. 2012, 50, 264-271. [CrossRef]

56. Moradi, V.; Ahmed, F.; Jun, M.B.G.; Blackburn, A.; Herring, R.A. Acid-Treated Fe-Doped $\mathrm{TiO}_{2}$ as a High Performance Photocatalyst Used for Degradation of Phenol under Visible Light Irradiation. J. Environ. Sci. 2019, 83, 183-194. [CrossRef] [PubMed]

57. Nahar, M.S.; Hasegawa, K.; Kagaya, S.; Kuroda, S. Comparative Assessment of the Efficiency of Fe-Doped TiO 2 Prepared by Two Doping Methods and Photocatalytic Degradation of Phenol in Domestic Water Suspensions. Sci. Technol. Adv. Mater. 2007, 8 , 286-291. [CrossRef]

58. Shawabkeh, R.; Khashman, O.; Bisharat, G. Photocatalytic Degradation of Phenol Using Fe-TiO 2 by Different Illumination Sources. Int. J. Chem. 2010, 2, 10. [CrossRef]

59. Yodsomnuk, P.; Junjeam, K.; Termtanun, M. Photoactivity of Fe and Zn-Doped $\mathrm{TiO}_{2}$ in Phenol Degradation under Visible Light. MATEC Web Conf. 2018, 192, 03047. [CrossRef]

60. Crişan, M.; Ianculescu, A.-C.; Crișan, D.; Drăgan, N.; Todan, L.; Niţoi, I.; Oancea, P. Chapter 10—Fe-Doped TiO 2 Nanomaterials for Water Depollution. In Nanotechnology in the Beverage Industry; Elsevier: Amsterdam, The Netherlands, 2020; pp. 265-313. [CrossRef]

61. Sun, T.; Liu, E.; Fan, J.; Hu, X.; Wu, F.; Hou, W.; Yang, Y.; Kang, L. High Photocatalytic Activity of Hydrogen Production from Water over Fe Doped and Ag Deposited Anatase $\mathrm{TiO}_{2}$ Catalyst Synthesized by Solvothermal Method. Chem. Eng. J. 2013, 228, 896-906. [CrossRef]

62. Moradi, H.; Eshaghi, A.; Hosseini, S.R.; Ghani, K. Fabrication of Fe-Doped $\mathrm{TiO}_{2}$ Nanoparticles and Investigation of Photocatalytic Decolorization of Reactive Red 198 under Visible Light Irradiation. Ultrason. Sonochem. 2016, 32, 314-319. [CrossRef] [PubMed] 